\title{
Role of Indole Acetic Acid (IAA) Producing Rhizobacteria and its Effect on Plant Growth of Mustard Crop under Salt Stress Condition
}

\author{
Kusum Sharma ${ }^{1 *}$, Swati Sharma ${ }^{1}$, Pawan Sharma ${ }^{2}$ and S. Rajendra Prasad ${ }^{3}$ \\ ${ }^{1}$ Integral University, Lucknow, U.P., India \\ ${ }^{2}$ ICAR-National Bureau of Agriculturally important microorganism, Mau, U.P., India \\ ${ }^{3}$ University of Agriculture and Sciences, Bangalore, India
}

*Corresponding author

\section{A B S T R A C T}

\section{Keywords}

Salinity, Salt tolerant, Abiotic stress, PGPR, Mitigation

Article Info

Accepted:

20 June 2019

Available Online:

10 July 2019
Rhizobacterial strains having plant growth promoting hormone can helps in promoting plant growth and mitigates adverse conditions. Keeping in view of their positive impact, present study was undertaken to identify the Salt Tolerant Rhizobacteria (STR) having IAA production activity. Out of 300 bacteria from the mustard rhizospheric soil 25 could able to grow at $10 \% \mathrm{NaCl}$ medium termed as STR were assessed for their plant growth promoting hormones. Bacterial strains (STR PGP) B1, B14, B17 and B25 identified as genus Enterobacter showing IAA production ranges from $1-3 \mu \mathrm{g} / \mathrm{ml}$. The seeds of salt sensitive mustard (var. Rohini) treated with these STRP GP were sown in pots subjected to salt stress $(5 \mathrm{M})$ along with untreated control without salt and STRPGP. At flowering stage, plant vigour and nutritional status was assessed that results an increased value of chlorophyll and flavonol in salt stressed plants as compared to control, while anthocynin remained almost same. The role of STRPGP under salt stress along with increased above parameters indicated the improved ability of mustard to sustain normal growth when subjected to stress condition.

\section{Introduction}

Salinization is recognized as one of the major constraints threatening natural resources in many countries and affects around one billion hectares of land worldwide (Munns and Tester, 2008). Salt stress is a major abiotic factor that turns agronomically useful lands into unproductive areas. Excessive salinity of soil inhibits crop growth and development, consequently, reducing yield and quality of crops. Mustard crops in India are grown in diverse agroclimatic conditions.

The Indian mustard, contributing nearly $80 \%$ of the total rabi oil seed production, is a vital component of edible oil sector constituting a total oilseed acreage and production in India 
which is $23.7 \%$ and $26.0 \%$, respectively (ICAR-CSSRI Vision 2030). The phytohormone auxin is one of other important factors to controls a maximum level of plant growth and development (Grossmann 2010). This phytoharmone play important role in much plant physiological activity like cell division, elongation, fruit development and senescence.

It was also reported by Phillips et al., 2011 that IAA initiates roots, leaves and flowers in plants and helps to promote growth development of plants. A potential strategy to improve mustard plant growth and yield under saline conditions is the commercial application of microbial inoculants in agricultural field.

PGPR are free living bacteria having beneficial effects on plants and they can improve plant growth and yield by indirect and direct mechanisms (Gupta et al., 2013).

Many of the microbes can do production of phytoharmone IAA under salt stress and the use of these kinds of microbes can improve plant growth under salt stress (Lugtenberg et al., 2013a). Application of PGPR in agriculture can enhance plant's resistance under adverse environmental stresses, was reported by many of the researchers like Glick et al., 2007; Dodd and Perez-Alfocea 2012; Berg et al., 2013.

They stimulate plant growth promotion by mobilizing nutrients, producing many plant growth promoting hormones. The present investigation is aimed to identify and characterize potential bacterial strains from soil having salt tolerance along with IAA production as PGPR to counter the adverse effects of salinity and to enhance plant growth promotion to improved yield and sustainability in mustard crop subjected to salinity stress.

\section{Materials and Methods}

Soil sampling and screening of Salt Tolerant Rhizobacterial strains

Mustard rhizospheric saline-sodic soil samples were collected from the different places of four district of Purvanchal region viz. Mau, Ballia, Gorakhpur and Varanasi, U.P India was mentioned in table 1. From the rhizospheric soil sample, bacteria were isolated in nutrient agar medium followed by serial dilution method. Screening of salt tolerant bacteria was done in $10 \% \mathrm{NaCl}$ supplemented Nutrient Agar medium plate assay and subsequently $10 \% \quad \mathrm{NaCl}$ supplemented Nutrient Broth Medium also. Both Nutrient Agar and Nutrient Broth cultures were incubated at $37^{\circ} \mathrm{C}$ for $48-72 \mathrm{hrs}$. On plate assay growth visible bacterial colonies were recorded while bacterial growth in nutrient broth were recorded by taking OD at $600 \mathrm{~nm}$ were found positive for salt tolerant rhizobacteria.

\section{Phytoharmone IAA production}

All the isolated salt tolerant bacterial (STB) strains were proceeds for their IAA production activity

\section{Indole Acetic Acid (IAA) production}

IAA production was performed as per description by Brick et al., 1991. A 24-48 hrs old fresh bacterial broth culture was centrifuged at $10,000 \mathrm{rpm}$ for $10 \mathrm{~min}$. From this centrifuged culture $2 \mathrm{ml}$ of supernatant was taken and subsequently 2 drop of orthophosphoric acid and Salkowski reagent $(50 \mathrm{ml}, 35 \%$ of Perchloric acid, $1 \mathrm{ml} 0.5 \mathrm{M}$ $\mathrm{FeCl}_{3}$ solution) is added in a test tube. Further the test tubes were incubated at room temp for 30 mints for the development of the pink colour and then intensity of pink colour was measured in spectrophotometer at $530 \mathrm{~nm}$. 
Further concentration of IAA produced was measured with the help of IAA standard graph.

\section{S sequencing}

An authenticated technique I6S rRNA sequence analysis is used to study bacterial isolates at species level (Imran et al., 2010; Alam et al., 2011). All the four amplified PCR product were outsourced for partial 16s sequencing from omega biotech limited (Kanpur (India) Pvt. All bacterial identification was performed using NCBI BLAST searches.

\section{Pot experiment}

A pot experiment was conducted using salt susceptible mustard plant var. Rohini in rabi season. Soil was autoclaved at $121^{\circ} \mathrm{C}$ for $1 \mathrm{hr}$ for three consecutive days and each pot was filled with $10 \mathrm{~kg}$ sterilized soil. A total of 18 pots including one positive control (without salt without bacteria), one negative control (with 5M salt and without bacterial treatment) and four potential bacterial isolates in 3 replications. Mustard seed (var. Rohini) were surface sterilized with distilled water then treated with each potential bacterial strains (50 ml i.e. $\sim 1 \times 10^{7}$ cells $\mathrm{ml}^{-1}$ ). Negative control represented without bacterial strain treated seeds in $5 \mathrm{M} \mathrm{NaCl}$ soil and the positive control represented the treatment with potential bacterial strains in normal soil without salt.

One gram of mustard seed were treated with each bacterial strain and incubated at normal temperature for $4 \mathrm{hrs}$ before sowing. Treated Seeds were air dried and then sown in pots filled with soil. The pots were kept under natural conditions and plants were raised. For maintaining uniform salt stress condition throughout the growth period, plants were regularly irrigated with $5 \mathrm{M}$ of salt solution after seven days interval.

\section{Results and Discussion}

The present study led to characterization of Salt tolerant Rhizobacteria (STR) having IAA production for the plant growth promoting activity on mustard crop subjected to salt stress. Identified 25 bacterial isolates were identified as genus Enterobacter by using using authenticating method of 16s rRNA PCR and NCBI BLAST searches. Four potential bacterial strains B1, B14, B17 and B25 having IAA production activities ranges from $2.2 \mu \mathrm{g} / \mathrm{ml}$ to $3 \mu \mathrm{g} / \mathrm{ml}$ (Fig. 1) were selected for further Pot studies. A pot trial for salt sensitive mustard crop var. rohini was conducted in November month under natural conditions. Seeds of mustard crops were treated with the mentioned above bacterial strains B1, B14, B17 and B25 along with a control without treatment of bacterial strains.

All the pots were filled with the autoclaved soil and $5 \mathrm{M}$ salt stress conditions was given in the pot with autoclaved soil. A comparative result was observed during the flowering stage when the physiological parameters of mustard crops were recorded with SPADMETER. Results shows an elevated value of chlorophyll, NBI (Nitrogen Binding Index) and flavenol in treated plants as compared to control without treatment while the value of anthocynin will remain same in all the conditions (Table 2). PGPR found in rhizospheric region can have beneficial role in plant growth promotion and their sustainability (Glick et al., 1999; Gerhardt et al., 2009). It was reported that the $16 \mathrm{~S}$ rRNA gene sequencing is one of the most common methods for the housekeeping genes to study bacterial genus/species classification (Imran $e t$ al., 2010; Alam et al., 2011). Identification of four bacterial isolates B1, B14, B17 and B25 bacterial species at genus/species level was done by the $16 \mathrm{~S}$ rRNA gene sequencing method and all four bacterial strains were identified as genus Enterobacter (Table 3). 
Table.1 Soil sampling sites and GPS locations

\begin{tabular}{|c|c|c|c|}
\hline District & Villages & GPS location & $\begin{array}{l}\text { Electric } \\
\text { conductivity } \\
\text { of soil }(\mu \mathrm{s} / \mathrm{cm})\end{array}$ \\
\hline \multirow[t]{4}{*}{ Gorakhpur } & Pipaganj & N-26 4453.448 E-83 2250.988 Elevation 56m & 689 \\
\hline & Doharighat & N-26 4453.448 E-83 2250.988 Elevation 56m & 689 \\
\hline & Sahjanva & N-26 4453.448 E-83 2250.988 Elevation 56m & 1151 \\
\hline & Khajni & N-25 4120.544 E-69 2834.068 Elevation 56m & 954 \\
\hline \multirow[t]{5}{*}{ Varanasi } & $\begin{array}{l}\text { Amra } \\
\text { Khera }\end{array}$ & N-25 21 8.28 E-85 58 31.224 Elevation 56m & 615 \\
\hline & Chaitipur & N-25 21 8.28 E-82 5831.224 Elevation 56m & 635 \\
\hline & $\begin{array}{l}\text { Suswahi } \\
\text { road }\end{array}$ & N-25 1538.088 E-82 5851.096 Elevation 56m & 645 \\
\hline & Tarna & N-25 218.28 E-82 5831.224 Elevation 56m & 526 \\
\hline & Ahirana & N-25 21 8.28 E-82 5831.224 Elevation 56m & 685 \\
\hline \multirow[t]{5}{*}{ Mau } & Baharvara & N-25 56.535 E-083 41.059 Elevation 56m & 728.58 \\
\hline & Haldharpur & N-25 57.967 E-083 41.609 Elevation 56m & 445 \\
\hline & Jagbhanpur & N-25 56.535 E-083 40.915 Elevation 57m & 658 \\
\hline & Sahupur & N-25 59.216 E-083 41.411 Elevation 98m & 425 \\
\hline & Ghosi & N-26 0636.00 E-083 32.240 & \\
\hline \multirow[t]{4}{*}{ Ballia } & Narla & N-26 06.043 E-083 56.148 Elevation 46m & 825 \\
\hline & Nadua & N-26 06.479 E-083 56.093 Elevation 47m & 978 \\
\hline & Narayanpur & N-26 06.265 E-083 57.823 Elevation 55m & 843 \\
\hline & Rampur & N-26 06.880 E-083 56.306 Elevation 50m & 768 \\
\hline
\end{tabular}

Table.2 Identification of isolated bacterial strains by partial 16s rRNA sequence analysis

\begin{tabular}{|l|l|l|l|}
\hline Isolate code & Genus and species & NCBI accession no. & 16s r RNA sequencing \\
\hline B1 & Enterobacter & MK446245 & Partial sequencing \\
\hline B14 & Enterobacter & MK463952 & Partial sequencing \\
\hline B17 & Enterobacter & MK 478371 & Partial sequencing \\
\hline B25 & Enterobacter & MK478386 & Partial sequencing \\
\hline
\end{tabular}


Table.3 Identification of isolated bacterial strains by partial 16s rRNA sequence analysis

\begin{tabular}{|c|c|c|c|c|c|c|c|c|c|c|c|}
\hline \multirow{2}{*}{$\begin{array}{l}\text { Leaf } \\
\text { (para } \\
\text { meter) }\end{array}$} & \multirow[b]{2}{*}{$\begin{array}{l}\text { Control } \\
\text { positive * } \\
\text { (without } \\
\text { sat and } \\
\text { without } \\
\text { bacterial } \\
\text { strain) }\end{array}$} & \multirow[b]{2}{*}{$\begin{array}{l}\text { Control } \\
\text { Negative** } \\
(5 \mathrm{M} \mathrm{NaCl} \\
\text { and no } \\
\text { bacterial } \\
\text { strains) }\end{array}$} & B1 & B2 & B3 & B4 & \multirow[t]{2}{*}{ C.D. } & \multirow{2}{*}{$\begin{array}{l}\text { SE } \\
\text { (m) }\end{array}$} & \multirow[t]{2}{*}{ C.V. } & \multirow{2}{*}{$\begin{array}{l}\text { F } \\
\text { value }\end{array}$} & \multirow{2}{*}{$\begin{array}{l}\text { Signifi } \\
\text { cance } \\
\text { level }\end{array}$} \\
\hline & & & \multicolumn{4}{|c|}{ (with $5 \mathrm{M} \mathrm{NaCl}$ ) } & & & & & \\
\hline NBI & 24.55 & 15.83 & 19.43 & 18.22 & 17.0 & 19.03 & 2.21 & 0.71 & 6.48 & 17.93 & $1 \%$ \\
\hline Chl & 31.13 & 19.64 & 27.8 & 24.93 & 25.23 & 27.3 & 3.37 & 1.08 & 7.22 & 12.49 & $1 \%$ \\
\hline Flav & 1.27 & 1.24 & 1.43 & 1.37 & 1.43 & 1.43 & 0.08 & 0.02 & 3.19 & 12.57 & $1 \%$ \\
\hline $\begin{array}{l}\text { Antho } \\
\text { cynin }\end{array}$ & 0 & 0.01 & 0 & 0.04 & 0.01 & 0,03 & N/A & & & & \\
\hline
\end{tabular}
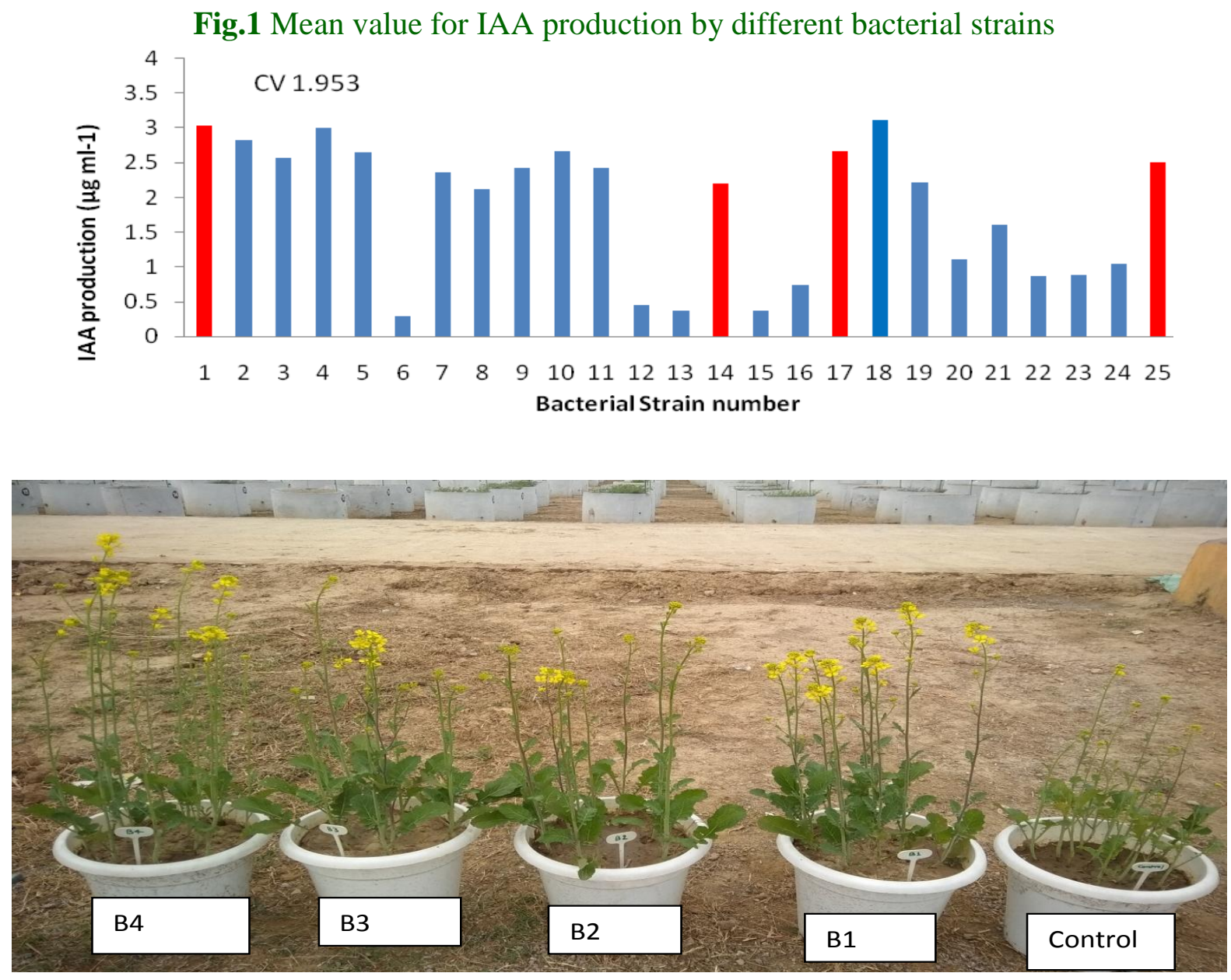

Pot $\mathrm{B} 4,3,2$ and 1 is bacteria treated plants along with control (without treatment)

Under salt stress conditions plant hormones can reduce water loss and cause a concomitant increase in leaf water potential rate (Aldesuquy and Ibrahim, 2001), so the 
problem can be overcome by the PGPR having salt tolerant and IAA production activity. Production of IAA by PGPR is a relatively common trait and believed to counteract salt stress in plants. It was reported that PGPR producing different plant growth promoting phytohormones can helps to promote plant growth development (Azcon and Barea, 1975; Sharma and Kaur, 2014). Invitro screening for the IAA production showed that all the identified four bacterial isolates have good efficiency to produce IAA. A variations in the IAA production observed by salt tolerant PGPR in the present study is consistent with earlier reports (Mansour et al., 1994; Zahir et al., 2000). Phytohormone Indole Acetic Acid (IAA), by PGPR is believed to support increase plant growth parameters, leading to enhanced uptake of nutrients thereby improving plant health under stress conditions (Egamberdieva and Kucharova, 2009).

It can be concluded that treatment of these salt tolerant bacterial strains with IAA application could alleviate the deleterious effect of salt stress on the growth and yield of mustard crop.

\section{References}

Alam, S.I., Bansod, S., Goel, A.K., and Singh, L, 2011. Characterization of an environmental strain of Bacillus thuringiensis from a hot spring in western Himalayas. Curr. Microbiol. 62: 547-556.doi:10.1007/s00284-0109743-x

Aldesuquy, H.S., Ibrahim, A.H., 2001. Interactive effect of seawater and growth bioregulators on water relations, abscisic acid concentration and yield of wheat plants. J Agron. Crop. Sci. 187: 185-93

Azcon R, Barea JM. Synthesis of auxins, gibberellins and cytokinins by
Azotobacter vinelandii and Azotobacter beijerinckii related to effects produced on tomato plants. Plants and Soil. 1975; 43: 609-619.

Berg,G., Alavi, M., Schmidt, C.S., Zachow, C., Egamberdieva, D., Kamilova, F., Lugtenberg, B., 2013. Biocontrol and osmoprotection for plants under salinated conditions. In: de Bruijn FJ (ed) Molecular microbial ecology of the rhizosphere. Hoboken, pp 561-573

Brick, J.M., Bostock, R.M. and Silverstone, S.E., 1991. Rapid in situ assay for indole acetic acid production by bacteria immobilized on nitrocellulose membrane. Appl Env. Microbiol 57: 535-538.

Dodd, I.C., Perez-Alfocea F., 2012. Microbial amelioration of crop salinity stress. J. Exp. Bot. 63: 3415-3428. 10.1093/jxb/ers033

Egamberdieva, D., and Kucharova, Z, 2009. Selection for root colonising bacteria stimulating wheat growth in saline soils. Biology and fertility of soils, 45(6), 563-571.

Glick et al., 2007 Glick, B.R. (2012). Plant growth - promoting bacteria: mechanisms and applications. Scientifica (Cairo). 2012, 963401963401.doi:10.6064/2012/963401

Grossmann K. 2010. Auxin herbicides: current status of mechanism and mode of action. Pest Management Science 66, 113-122.

Gupta, G.N., Khan, M.K. and Prakash, V., 2013. Revelation of the phosphate solubilizing abilities of soil bacteria and its role in plants growth promotion. Int. J. of Recent Sci. Res., 4(4): 353 -356

Lugtenberg B, Malfanova N, Kamilova F, Berg G (2013) Microbial control of plant root diseases and plant growth promotion by microbes In: De Bruijn FJ (ed) Molecular microbial ecology of the 
rhizosphere, $\quad$ Chapter 54. Wiley/Blackwell, New York, pp 575586

Mansour, F.A., Ildesuguy, H.S., and Hamedo, H.A. (1994). Studies on plant growth regulators and enzyme production by some bacteria. J. Qatar Univ. Sci. 14, 81-288

Sharma S, Kaur M. Effect of different nutrient sources on the production of plant growth regulators (PGRs) by fluorescent Pseudomonas species. Indian Journal of Applied Research. 2014; 4(10): 468-471.

Zahir, A. Abbas, S.A., Khalid, M., and Arshad, M. (2000). Structure dependent microbially derived plant hormones by improving growth of maize seedlings. Pak. J. Biol. Sci. 3, 289-291. doi:10.3923/pjbs.2000.289.291

\section{How to cite this article:}

Kusum Sharma, Swati Sharma, Pawan Sharma and Rajendra Prasad, S. 2019. Role of Indole Acetic Acid (IAA) Producing Rhizobacteria and its Effect on Plant Growth of Mustard Crop under Salt Stress Condition. Int.J.Curr.Microbiol.App.Sci. 8(07): 2439-2445.

doi: https://doi.org/10.20546/ijcmas.2019.807.300 